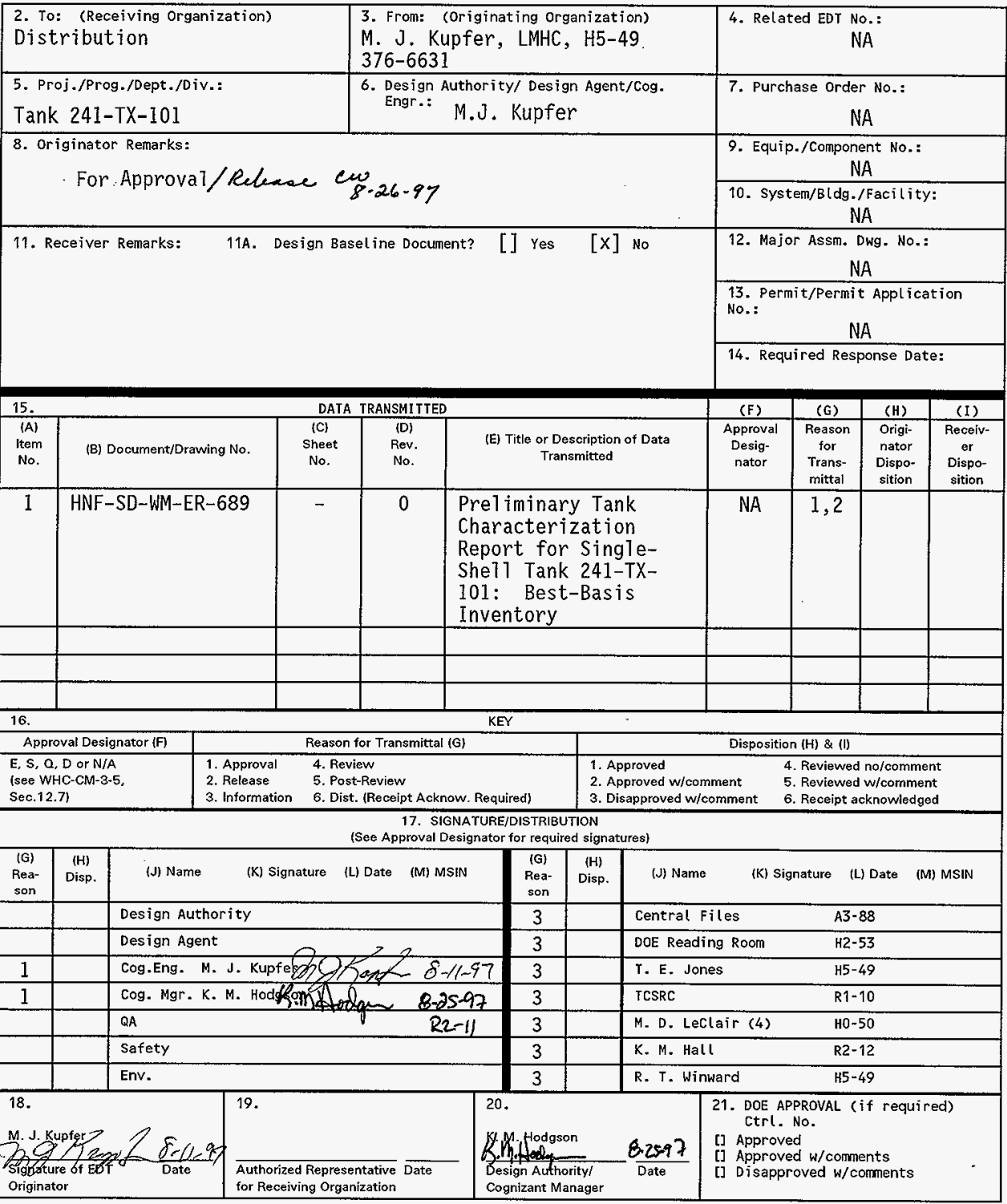

BD-7400-172-2 (05/96) GEF097 


\section{Preliminary Tank Characterization Report for Single-Shell Tank 241-TX-101: Best-Basis Inventory}

T. E. Jones (Meier Associates), R. T. Winward (Meier Associates), and M. J. Kupfer Lockheed Martin Hanford Corporation, Richland, WA 99352

U.S. Department of Energy Contract DE-AC06-96RL13200

EDT/ECN: 161470

UC: 712

Org Code: $746 / 0$

Charge Code: $N 4 G 3 A$

B\&R Code: EW3120074 Total Pages: $31 \mathrm{cw}_{8-26-97}$

Key Words: TCR, best-basis inventory

Abstract: - An effort is underway to provide waste inventory estimates that will serve as standard characterization source terms for the varjous waste management activities. As part of this effort, an evaluation of available information for single-shell tank 241-TX-101 was performed, and a best-basis inventory was established. This work follows the methodology that was established by the standard inventory task.

TRADEMARK DISCLAIMER. Reference herein to any specific commercial product, process, or service by trade name, trademark, manufacturer, or otherwise, does not necessarily constitute or imply its endorsement, recommendation, or favoring by the United States Government or any agency thereof or its contractors or subcontractors.

Printed in the United States of America. To obtain copies of this document, contact: Document Control Services, P.O. BOX 950, Mailstop H6-08, Richland WA 99352, Phone (509) 372-2420;

Fax (509) 376-4989.
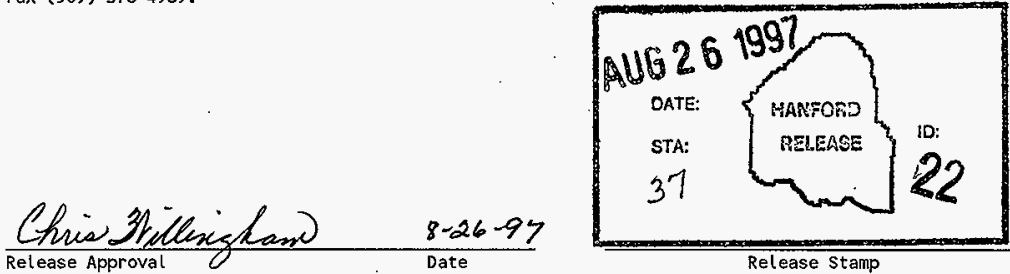


\title{
PRELIMINARY TANK \\ CHARACTERIZATION REPORT \\ FOR SINGLE-SHELL TANK \\ 241-TX-101: \\ BEST-BASIS INVENTORY
}

\author{
April 1997 \\ M. J. Kupfer \\ Lockheed Martin Hanford Corporation \\ Richland, Washington \\ T. E. Jones \\ R. T. Winward \\ Meier Associates \\ Ricbland, Washington
}

Prepared for

U.S. Department of Energy

Richland, Washington 


\section{HNF-SD-WM-ER-689}

Revision 0

This page intentionally left blank. 
HNF-SD-WM-ER-689

Revision 0

\section{PRELIMINARY TANK CHARACTERIZATION REPORT FOR SINGLE-SHELL. TANK 241-TX-101: BEST-BASIS INVENTORY}

This document is a preliminary Tank Characterization Report (TCR). It only contains the current best-basis inventory (Appendix D) for single-shell tank 241-TX-101. No TCRs have been previously issued for this tank, and current core sample analyses are not available. The best-basis inventory, therefore, is based on an engineering assessment of waste type, process flowsheet data, early sample data, and/or other available information.

The Standard Inventories of Chemicals and Radionuclides in Hanford Site Tank Wastes (Kupfer et al. 1997) describes standard methodology used to derive the tank-by-tank best-basis inventories. This preliminary TCR will be updated using this same methodology when additional data on tank contents become available.

\section{REFERENCE}

Kupfer, M. J., A. L. Boldt, B. A. Higley, K. M. Hodgson, L. W. Shelton, B. C. Simpson, and R. A. Watrous (LMHC), S. L. Lambert, and D. E. Place (SESC), R. M. Orme (NHC), G. L. Borsheim (Borsheim Associates), N. G. Colton (PNNL), M. D. LeClair (SAIC), R. T. Winward (Meier Associates), and W. W. Schulz (W²S Corporation), 1997, Standard Inventories of Chemicals and Radionuclides in Hanford Site Tank Wastes, HNF-SD-WM-TI-740, Rev. 0, Lockheed Martin Hanford Corporation, Richland, Washington. 
HNF-SD-WM-ER-689

Revision 0

This page intentionally left blank. 
HNF-SD-WM-ER-689

Revision 0

\section{APPENDIX D}

\section{EVALUATION TO ESTABLISH BEST-BASIS INVENTORY FOR SINGLE-SHELL TANK 241-TX-101}


HNF-SD-WM-ER-689

Revision 0

This page intentionally left blank.

D-2 
HNF-SD-WM-ER-689

Revision 0

APPENDIX D

\section{EVALUATION TO ESTABLISH BEST-BASIS INVENTORY FOR SINGLE-SHELL TANK 241-TX-101}

An effort is underway to provide waste inventory estimates that will serve as standard characterization source terms for the various waste management activities (Hodgson and LeClair 1996). As part of this effort, an evaluation of available information for single-shell tank (SST) 241-TX-101 was performed, and the best-basis inventory was established. This work, detailed in the following sections, follows the methodology that was established by the standard inventory task.

\section{D1.0 CHEMICAL INFORMATION SOURCES}

There is no previous Tank Characterization Report (TCR) for SST 241-TX-101. Available waste (chemical) information for tank 241-TX-101 includes the following:

- The TCRs from tank 241-U-102 (Hu et al. 1997) and 241-U-105 (Brown and Franklin 1996) provide relevant information and discuss waste layers within those tanks that are believed to contain the same salt cake waste type as expected to be in tank 241-TX-101.

- The TCRs from tank 241-S-101 (Kruger et al. 1996), tank 241-S-104 (DiCenso et al. 1994), and tank 241-S-107 (Simpson et al. 1996) discuss waste layers within those tanks that are believed to contain the same reduction and oxidation (REDOX) sludge waste type as expected to be in tank 241-TX-101.

- Letter report on tank 241-TX-116 (Horton 1977)

- The inventory estimate for this tank generated from the Hanford Defined Waste model (HDW) (Agnew et al. 1997), developed at Los Alamos National Laboratory (LANL).

A list of references used in this evaluation is provided in Section D5.0. 
HNF-SD-WM-ER-689

Revision 0

\section{D2.0 COMPARISON OF COMPONENT INVENTORY VALUES}

The HDW model inventories are shown in Tables D2-1 and D2-2. The nonradioactive components are listed in Table D2-1 on a kilogram (kg) basis. The radioactive component estimates are listed in Table D2-2 on a curie (Ci) basis. No sample-based inventories are available for this tank. The HDW model document (Agnew et al. 1997) provides tank content estimates derived from process history. (The chemical species are reported without charge designation per the best-basis inventory convention.)

Table D2-1. Hanford Defined Waste Model-Based Inventory Estimates for Nonradioactive Components in Tank 241-TX-101.

\begin{tabular}{|c|c||c|c|}
\hline Analyte $^{\mathrm{a}}$ & $\begin{array}{c}\mathrm{HDW}^{\mathrm{b}} \text { Inventory } \\
\text { Estimate (kg) }\end{array}$ & Analyte $^{\mathrm{a}}$ & $\begin{array}{c}\text { HDW } \\
\text { Estimate (kg) }\end{array}$ \\
\hline $\mathrm{Al}$ & 52,600 & $\mathrm{Ni}$ & 823 \\
\hline $\mathrm{Bi}$ & 8.29 & $\mathrm{NO}_{2}$ & 21,600 \\
\hline $\mathrm{Ca}$ & 2,480 & $\mathrm{NO}_{3}$ & 97,300 \\
\hline $\mathrm{Cl}$ & 778 & $\mathrm{OH}$ & 126,000 \\
\hline $\mathrm{Cr}$ & 1,130 & $\mathrm{Oxalate}$ & 0 \\
\hline $\mathrm{F}$ & 36.9 & $\mathrm{~Pb}$ & 6.39 \\
\hline $\mathrm{Fe}$ & 15,400 & $\mathrm{PO}_{4}$ & 691 \\
\hline $\mathrm{Hg}$ & 0.0559 & $\mathrm{Si}$ & 131 \\
\hline $\mathrm{K}$ & 200 & $\mathrm{SO}_{4}$ & 1,090 \\
\hline $\mathrm{Mn}$ & 6.42 & $\mathrm{TIC} \mathrm{as} \mathrm{CO}_{3}$ & 5,690 \\
\hline $\mathrm{Na}$ & 61,800 & $\mathrm{TOC}$ & 361 \\
\hline $\mathrm{NH}$ & 1,200 & $\mathrm{U}_{\text {TOTAL }}$ & 4,910 \\
\hline $\mathrm{H}_{2} \mathrm{O}(\mathrm{wt} \%)$ & 30.4 & $\mathrm{Zr}$ & 0.695 \\
\hline Density $(\mathrm{g} / \mathrm{mL})$ & 1.70 & & \\
\hline $\mathrm{HDW}$ & \multicolumn{2}{|}{} \\
\hline
\end{tabular}

HDW $=$ Hanford Defined Waste

${ }^{2}$ No sample-based inventory

${ }^{b}$ Agnew et al. (1997). 
HNF-SD-WM-ER-689

Revision 0

Table D2-2. Hanford Defined Waste Model-Based Inventory Estimates for Radioactive Components in Tank 241-TX-101.

\begin{tabular}{|c|c|}
\hline Analyte $^{\mathrm{a}}$ & HDW inventory estimate $^{\mathrm{b}}(\mathrm{Ci})$ \\
\hline${ }^{90} \mathrm{Sr}$ & 250,000 \\
\hline${ }^{137} \mathrm{Cs}$ & 24,100 \\
\hline${ }^{239} \mathrm{Pu}$ & 232 \\
\hline
\end{tabular}

HDW $=$ Hanford Defined Waste

${ }^{a}$ No sample-based inventory

${ }^{b}$ Agnew et al. (1997), decayed to January 1, 1994.

\section{D3.0 COMPONENT INVENTORY EVALUATION}

The following evaluation was conducted to assess various estimates of tank contents.

\section{D3.1 WASTE HISTORY TANK 241-TX-101}

Tank 241-TX-101 began filling in July 1949 with metal waste. The tank was utilized in the metal waste recovery activities and was sluiced in 1954, 1955, 1956, and 1957. It was declared empty in the first quarter of 1957 (Rodenhizer 1987). From the second quarter of 1957 until the third quarter of 1971 the tank periodically received REDOX waste. From 1971 until the second quarter of 1976 the tank contained a mixture of wastes from REDOX, plutonium-uranium extraction (PUREX), B Plant, N Reactor, 242-T Evaporator, and various laboratory wastes. In the third quarter of 1976 the waste was classified as evaporator feed. In the first quarter of 1978 the waste was reclassified as non-complexed. From the third quarter of 1979 until the first quarter of 1980, the tank contained partially neutralized feed. In the second quarter of 1980 the waste was again classified as non-complexed.

The tank was labeled inactive in 1980 and was interim stabilized in February 1984. Intrusion prevention was completed in August 1984. The tank is classified as a sound stabilized tank. For a more complete history of the waste in this tank refer to the supporting document (Brevick 1995). 
HNF-SD-WM-ER-689

Revision 0

\section{D3.2 EXPECTED TYPE OF WASTE BASED ON THIS ASSESSMENT}

The following are reported waste types in tank 241-TX-101:

Agnew et al. (1995, 1997): R, SMMT2, Z, and MW

Hanlon (1996): salt cake

Hill (1995): R, EB, and MIX

$\mathrm{MW}=$ Metal waste

SMMT2 = A mixture of concentrated supernatant coming from the 242-T

Evaporator that are a blend of other waste types that upon cooling precipitated as a salt cake

$\mathrm{R}=$ High-level REDOX waste

$\mathrm{Z} \quad=\mathrm{Z}$ Plant wastes

$\mathrm{EB}=$ Evaporator bottoms (similar to SMMT2)

MIX $=$ Mixture of several miscellaneous wastes

Agnew et al. (1995, 1997), Hanlon (1996), and Hill et al. (1995) list the waste volume in tank 241-TX-101 as $329.3 \mathrm{~kL}$ ( $87 \mathrm{kgal}$ ). Hanlon and Hill et al. identify the waste as 318 $\mathrm{kL}$ (84 kgal) sludge and $11.4 \mathrm{~kL}$ (3 kgal) supernatant. Agnew et al. (1997) separates the waste into a $280.1 \mathrm{~kL}(74 \mathrm{kgal})$ sludge layer and a $49.2 \mathrm{~kL}$ (13 kgal) supernatant mixing model (SMM) composite. The SMM composite is assigned as $37.9 \mathrm{~kL}$ (10 kgal) of SMMT2 solids and $11.4 \mathrm{~kL}(3 \mathrm{kgal})$ of SMMT2 supernatant.

Agnew et al. (1997) identifies the sludge layer as $265 \mathrm{~kL}$ (70 kgal) R1 sludge, $11.4 \mathrm{~kL}$ (3 kgal) metal waste (MW) and $3.79 \mathrm{~kL}(1 \mathrm{kgal}) \mathrm{Z}$ Plant waste.

This engineering assessment treats the sludge as R1. It is assumed the all metal waste was sluiced out of the tank (Rodenhizer 1987) and the quantity of Z Plant waste (if it exists in this tank) is too small to contribute to the overall tank inventory. It also treats all of the SMM composite as SMMT2 solids and assumes no supernatant is remaining in tank 241-TX-101.

\section{D3.3 ASSUMPTIONS USED}

The evaluation provides an engineering assessment of tank 241-TX-101 contents. For this evaluation, the following assumptions and observations are made:

- Component inventories can be calculated by multiplying the average concentration of an analyte from a group of similar tanks by the current tank volume and density estimate of the waste of the specific tank.

- The tank is assumed to contain a REDOX waste type sludge layer and a salt cake from the 242-T Evaporator. 
- The radiolysis of nitrate to nitrite is not factored into this evaluation.

There are limited chemical characterization data for tanks in the TX tank farm and few sampled tanks contain salt cake similar to that reported to be in 241-TX-101. The HDW model identifies the salt cake waste in 241-TX-101 to be SMMT2. The only chemical characterization data for SMMT2 waste appear to be from three tanks (241-U-102, 241-U-105, and 241-TX-116).

Based on information from TCRs for the two U Tank Farm tanks. (241-U-102 [Hu et al. 1997] and 241-U-105 [Brown and Franklin 1996]), the SMMT2 waste was identified in the lower parts of each tank. Tank 241-TX-116 was core sampled in 1976 and limited characterization data are available from that effort (Horton 1977). The data from tank 241-TX-116 were used along with data from the two U Tank Farm tanks to develop an SMMT2 salt cake formulation. Although the potential problems associated with using analytical data generated in the 1970 's are well recognized, these are the only available measurements that may reflect early SMMT2 salt cake compositions.

This engineering assessment assumes the sludge layer in tank 241-TX-101 to be comparable with the R1 Sludge composition developed from analytical data reported in TCRs for tanks 241-S-101 (Kruger et al. 1996), 241-S-104 (DiCenso et al. 1994) and 241-S-107 (Simpson et al. 1996).

\section{D3.4 BASIS FOR CALCULATIONS USED IN THIS ENGINEERING EVALUATION}

Table D3-1 shows the engineering approaches used for Tank 241-TX-101.

Table D3-1. Engineering Approaches Used for Tank 241-TX-101. (2 Sheets)

\begin{tabular}{|l|l|l|}
\hline \multicolumn{1}{|c|}{ Type of waste } & \multicolumn{1}{c|}{ How calculated } & \multicolumn{1}{c|}{ Check method } \\
\hline Supernatant & $\begin{array}{l}\text { Assumed to be part of } \\
\text { SMMT2 }\end{array}$ & None \\
\hline $\begin{array}{l}\text { SMMT2 Salt Cake } \\
\text { Volume } \\
\text { Density }=49.2 \mathrm{~kL}(13 \mathrm{kgal})\end{array}$ & $\begin{array}{l}\text { Used sample-based } \\
\text { concentrations from other } \\
\text { tanks with SMMT2 salt } \\
\text { cake waste. See } \\
\text { Table D3-2. }\end{array}$ & $\begin{array}{l}\text { None, no sample-based } \\
\text { information available for } \\
\text { this tank. }\end{array}$ \\
\hline
\end{tabular}


HNF-SD-WM-ER-689

Revision 0

Table D3-1. Engineering Approaches Used for Tank 241-TX-101. (2 Sheets)

\begin{tabular}{|c|c|c|}
\hline Type of waste & How calculated & Check method \\
\hline $\begin{array}{l}\text { R1 Sludge } \\
\text { Volume }^{a}=280.1 \mathrm{~kL}(74 \mathrm{kgal}) \\
\text { Density }=1.77 \mathrm{~g} / \mathrm{mL}\end{array}$ & $\begin{array}{l}\text { Used sample-based data } \\
\text { from S Tank Farm tanks to } \\
\text { develop the R1 sludge } \\
\text { composition estimate. See } \\
\text { Table D3-4. }\end{array}$ & $\begin{array}{l}\text { None, no sample-based } \\
\text { information available for } \\
\text { this tank. }\end{array}$ \\
\hline
\end{tabular}

R1 = REDOX high-level waste generated between 1952 to 1957

SMMT2 = Supernatant Mixing Model 242-T Evaporator salt cake generated from 1965 until 1976

Agnew et al. (1997).

The general approach in this engineering assessment is to identify waste types and their approximate volumes within the tank of interest. The sources of information may include analytical data from samples taken from the tank of interest, analytical data from other tanks believed to contain waste types similar to those believed to be in the tank of interest, and data from models utilizing history process records.

The confidence level assigned to the best-basis inventory values then depends on the level of agreement among the various information sources. This approach is best suited for cases where extensive analytical data exist for multiple sampling events from the tank of interest and from a number of other tanks containing similar waste types. However, for tank 241-TX-101, no tank specific analytical data and very little analytical data are available for the SMMT2 salt cake projected to be in that tank. A REDOX sludge composition developed from analytical data from S Tank Farm tanks was used for the sludge layer in tank 241-TX-101.

\section{D3.4.1 Basis For Salt Cake Calculations Used In This Engineering Evaluation}

A review of existing TCRs identified two that contained contemporary analytical characterization data that could be assigned to layers of SMMT2 salt cake. In addition, limited characterization data were available from core samples taken from 241-TX-116 in the mid-1970's.

Analytical data from segments 4 through 6 from tank 241-U-102 and segment 8 from tank 241-U-105 were selected as being representative of SMMT2 salt cake. For almost all selected analytes, there were 14 data points from tank $241-\mathrm{U}-102$ and 4 data points from tank 241-U-105.

To correct for material recovery during sampling, a weighted mean was calculated from selected data for each U Tank Farm tank. The approach was to multiply each data point by the weight of the core sample recovered. This "product" was summed, as were the weights 
of individual samples. Finally, the summed product was divided by the total weight of recovered core samples.

The weighted means for each tank are listed in columns 2 and 3 of Table D3-2. The U Tank Farm means were calculated from each tank mean, again after including a factor to correct for material recovery during sampling, and are listed in column 4 of Table D3-2. The means from tank 241-TX-116 are also listed in column 5 of Table D3-2. The tank 241-TX-116 means were calculated after removing high silica values resulting from the addition of diatomaceous earth to the tank.

The predicted composition for the SMMT2 salt cake was calculated as the simple average of the U Tank Farm weighted means and tank 241-TX-116 means. The predicted SMMT2 composition is listed in column 6 of Table D3-2. The major impact of including characterization data from tank 241-TX-116 in the predicted SMMT2 salt cake composition is to significantly increase values for $\mathrm{Al}$ and $\mathrm{Fe}$.

Table D3-2. Composition of T2 Salt Cakes. (3 Sheets)

\begin{tabular}{|c|c|c|c|c|c|c|}
\hline Analyte & $\begin{array}{c}241-\mathrm{U}-102 \\
\text { T2 salt cake } \\
\text { wt. avg., } \\
(\mu \mathrm{g} / \mathrm{g})\end{array}$ & $\begin{array}{c}241-\mathrm{U}-105 \\
\mathrm{~T} 2 \text { salt cake } \\
\text { wt. avg.,., } \\
(\mu \mathrm{g} / \mathrm{g})\end{array}$ & $\begin{array}{c}\text { U Tank } \\
\text { Farm } \\
\text { T2 sait } \\
\text { cake } \\
\text { wt. avg.a } \\
(\mu \mathrm{g} / \mathrm{g}) \\
\end{array}$ & $\begin{array}{c}241-\mathrm{TX}-116 \\
\text { T2 salt cake } \\
\text { mean }^{\mathrm{d}, e} \\
(\mu \mathrm{g} / \mathrm{g})\end{array}$ & $\begin{array}{c}\text { T2 salt } \\
\text { cake } \\
\text { prediction }^{\mathrm{f}} \\
(\mu \mathrm{g} / \mathrm{g})\end{array}$ & $\begin{array}{c}\text { HDW } \\
\text { T2 SltCk } \\
(\mu \mathrm{g} / \mathrm{g})\end{array}$ \\
\hline $\mathrm{Ag}$ & 11.6 & 19.7 & 13.1 & NR & 13.1 & NR \\
\hline $\mathrm{Al}$ & 18,000 & 12,900 & 17,100 & 38,000 & 27,500 & 17,912 \\
\hline $\mathrm{Bi}$ & $<70.5$ & $<47.2$ & $<66.2$ & $\mathrm{NR}$ & $<66.2$ & 220.81 \\
\hline $\mathrm{Ca}$ & 308 & 253 & 298 & NR & 298 & 1,462 \\
\hline $\mathrm{Cd}$ & $<5.94$ & 12.8 & $<7.21$ & NR & $<7.21$ & NR \\
\hline $\mathrm{Cl}$ & 5,100 & 5,790 & 5,230 & NR & 5,230 & $3,327.8$ \\
\hline $\mathrm{CO}_{3}$ & 53,500 & 36,500 & 50,300 & 58,000 & 54,200 & 17,093 \\
\hline $\mathrm{Cr}$ & 2,310 & 2,100 & 2,270 & 353 & 1,310 & 4259.6 \\
\hline$F$ & $<125$ & 1,110 & $<307$ & 3,540 & $<1,920$ & 930.79 \\
\hline $\mathrm{Fe}$ & 391 & 2,270 & 737 & 23,900 & 12,300 & 620.58 \\
\hline $\mathrm{Hg}$ & NR & NR & $\mathrm{NA}$ & NR & NA & 1.1338 \\
\hline $\mathrm{K}$ & 1750 & 1,470 & 1,700 & $\mathrm{NR}$ & 1,700 & 1060.7 \\
\hline $\mathrm{La}$ & $<35.2$ & 29.7 & $<34.2$ & NR & $<34.2$ & 0.0001 \\
\hline $\mathrm{Mn}$ & 123 & 743 & 237 & NR & 237 & 160.31 \\
\hline $\mathrm{Na}$ & 262,600 & 220,500 & 254,800 & 166,700 & 210,800 & 192,764 \\
\hline
\end{tabular}


HNF-SD-WM-ER-689

Revision 0

Table D3-2. Composition of T2 Salt Cakes. (3 Sheets)

\begin{tabular}{|c|c|c|c|c|c|c|}
\hline Analyte & $\begin{array}{c}241-\mathrm{U}-102 \\
\text { T2 salt cake } \\
\text { wt. avg.a,b } \\
(\mu \mathrm{g} / \mathrm{g})\end{array}$ & $\begin{array}{c}241-\mathrm{U}-105 \\
\text { T2 salt cake } \\
\text { wt. avg., } \\
(\mu \mathrm{g} / \mathrm{g})\end{array}$ & $\begin{array}{c}\text { U Tank } \\
\text { Farm } \\
\text { T2 salt } \\
\text { cake } \\
\text { wt. avg. }{ }^{2} \\
(\mu \mathrm{g} / \mathrm{g})\end{array}$ & $\begin{array}{c}\text { 241-TX-116 } \\
\text { T2 salt cake } \\
\text { mean }^{\mathrm{d}, \mathrm{e}} \\
(\mu \mathrm{g} / \mathrm{g})\end{array}$ & $\begin{array}{c}\text { T2 salt } \\
\text { cake } \\
\text { prediction }^{\mathrm{f}} \\
(\mu \mathrm{g} / \mathrm{g})\end{array}$ & $\begin{array}{c}\text { HDW } \\
\text { T2 SItCK } \\
(\mu \mathrm{g} / \mathrm{g})\end{array}$ \\
\hline $\mathrm{Ni}$ & 91.5 & 89.5 & 91.1 & NR & 91.1 & 405.82 \\
\hline $\mathrm{NO}_{2}$ & 56,700 & 40,100 & 53,600 & 7,840 & 30,700 & 46,096 \\
\hline $\mathrm{NO}_{3}$ & 284,700 & 395,700 & 305,200 & 308,700 & 306,946 & 268,197 \\
\hline $\mathrm{OH}$ & NR & NR & NA & NA & NA & 68,079 \\
\hline $\mathrm{Pb}$ & $<119$ & 214 & $<136$ & NR & $<136$ & 109.91 \\
\hline $\mathrm{P}$ as $\mathrm{PO}_{4}$ & 5,050 & 14,100 & 6,720 & 8,620 & 7,670 & $7,707.9$ \\
\hline $\mathrm{Si}$ & 152 & 232 & 167 & NR & 167 & $1,817.7$ \\
\hline $\mathrm{S}$ as $\mathrm{SO}_{4}$ & 17,900 & 8,350 & 16,200 & 16,400 & 16,300 & 13,823 \\
\hline $\mathrm{Sr}$ & $<7.04$ & $<4.72$ & $<6.61$ & NR & $<6.61$ & 0 \\
\hline TOC & 8,810 & 11,000 & 9,210 & NR & 9,210 & 5,191 \\
\hline $\mathrm{U}$ & $<353$ & 545 & $<388$ & NR & $<388$ & $2,174.3$ \\
\hline $\mathrm{Zr}$ & 10.8 & 45.4 & 17.2 & NR & 17.2 & 14.707 \\
\hline \multicolumn{7}{|c|}{$\operatorname{Radionuclide}^{\mathrm{h}}(\mu \mathrm{Ci} / \mathrm{g})$} \\
\hline${ }^{241} \mathrm{Am}$ & $<37.0$ & $<0.95$ & $<30.3$ & NR & $<30.3$ & 0.0285 \\
\hline${ }^{60} \mathrm{Co}$ & $<0.155$ & 0.086 & $<0.142$ & $\mathrm{NR}$ & $<0.142$ & 0.027 \\
\hline${ }^{134} \mathrm{Cs}$ & NR & NR & NA & $9.64 \mathrm{E}-04$ & $9.64 \mathrm{E}-04$ & 0.0016 \\
\hline${ }^{137} \mathrm{Cs}$ & 197 & 145 & 188 & 34.8 & 111 & 163.24 \\
\hline${ }^{154} \mathrm{Eu}$ & $<0.475$ & 0.61 & $<0.499$ & NR & $<0.499$ & 0.431 \\
\hline${ }^{155} \mathrm{Eu}$ & $<1.10$ & 0.82 & $<1.05$ & NR & $<1.05$ & 0.1849 \\
\hline
\end{tabular}


HNF-SD-WM-ER-689

Revision 0

Table D3-2. Composition of T2 Salt Cakes. (3 Sheets)

\begin{tabular}{|c|c|c|c|c|c|c|}
\hline Analyte & $\begin{array}{c}\text { 241-U-102 } \\
\text { T2 salt cake } \\
\text { wt. avg., } \\
(\mu \mathrm{g} / \mathrm{g})\end{array}$ & $\begin{array}{c}241-\mathrm{U}-105 \\
\text { T2 salt cake } \\
\text { wt. avg., } \\
(\mu \mathrm{g} / \mathrm{g})\end{array}$ & $\begin{array}{c}\text { U Tank } \\
\text { Farm } \\
\text { T2 salt } \\
\text { cake } \\
\text { wt. avg. } \\
(\mu \mathrm{g} / \mathrm{g})\end{array}$ & $\begin{array}{c}\text { 241-TX-116 } \\
\text { T2 salt cake } \\
\text { mean }^{\mathrm{d}, \mathrm{e}} \\
(\mu \mathrm{g} / \mathrm{g})\end{array}$ & $\begin{array}{c}\text { T2 salt } \\
\text { cake } \\
\text { rediction }^{\mathrm{f}} \\
(\mu \mathrm{g} / \mathrm{g})\end{array}$ & $\begin{array}{c}\text { HDW } \\
\text { T2 SltCkg } \\
(\mu \mathrm{g} / \mathrm{g})\end{array}$ \\
\hline $\begin{array}{c}\text { Density } \\
(\mathrm{g} / \mathrm{mL})\end{array}$ & 1.66 & 1.73 & $1.70^{\mathrm{i}}$ & NR & 1.70 & 1.634 \\
\hline
\end{tabular}

HDW $=$ Hanford Defined Waste

$\mathrm{NA}=$ Not applicable

$\mathrm{NR}=$ Not reported

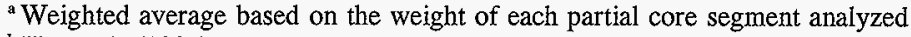

${ }^{\mathrm{b}} \mathrm{Hu}$ et al. (1997)

${ }^{\circ}$ Brown and Franklin (1996)

${ }^{\mathrm{d}}$ Silica-free basis due to the addition of diatomaceous earth to this tank

'Horton (1977)

${ }^{\mathrm{f}}$ Average of U Tank Farm and tank 241-TX-116 data

${ }^{g}$ Agnew et al. (1997)

${ }^{\text {h }}$ Decayed to January 1,1994

${ }^{i}$ A simple average is used for the density.

In comparing the engineering estimates based on SMMT2 salt cake (Table D3-2, column 6) with the HDW T2 salt cake estimates (Table D3-2, column 7), differences of over a factor of three are noted for Fe and carbonate. Smaller differences are noted for $\mathrm{Al}, \mathrm{Ca}$, $\mathrm{K}, \mathrm{Mn}, \mathrm{Na}$, and nitrate. The Fe values used in the developing the SMMT2 formulation exhibited large variations. There is close to an order of magnitude difference in $\mathrm{Fe}$ between the two U Tank Farm tanks. The Fe value for tank-241-TX-116 is an order of magnitude higher than the larger U Tank Farm tank value. The HDW model predicts an Fe value comparable with the lower U Tank Farm tank value. Because the analytical values span almost two orders of magnitude, there will be considerable uncertainty in the projected $\mathrm{Fe}$ value for tank 241-TX-101. Since the value developed through this engineering assessment appears unreasonably high based on the solubility of Fe in alkaline solutions, the U Tank Farm estimate is used as the best-basis value for Fe.

The three analytically determined carbonate values used to develop the SMMT2 formulation are reasonably consistent. However, these values are significantly higher than the value determined by the HDW model. It is likely that the highly basic tank wastes have absorbed atmospheric carbon dioxide. Absorption of carbon dioxide would convert hydroxide to carbonate.

Table D3-3 lists the inventory estimates calculated using the predicted SMMT2 composition and the $\mathrm{U}$ Tank Farm composition. The HDW model estimates are also 
included. The bulk density value used in the engineering assessment estimates $(1.70 \mathrm{~g} / \mathrm{mL})$ is approximately 20 percent higher than the value ussed in the HDW model estimates $(1.40 \mathrm{~g} / \mathrm{mL})$. This leads to proportionally higher estimates in the engineering estimate.

Table D3-3. Tank 241-TX-101 Inventory Estimates for the SMMT2 Salt Cake Layer (Volume $=49.2 \mathrm{~kL}[13 \mathrm{kgal}]$ ). (2 Sheets)

\begin{tabular}{|c|c|c|c|}
\hline Analyte & $\begin{array}{l}\text { Inventory estimates } \\
\text { using T2SltCk } \\
\text { average } \\
\text { concentrations } \\
(\mathrm{kg})\end{array}$ & $\begin{array}{c}\text { Inventory estimates } \\
\text { using } U \text { tank farm } \\
\text { weighted mean } \\
\text { concentration } \\
(\mathrm{kg})\end{array}$ & $\begin{array}{l}\text { HDW-Based Inventory for } \\
\text { T2SltCk layer }{ }^{\mathrm{a}} \\
(\mathrm{kg})\end{array}$ \\
\hline $\mathrm{Al}$ & 2,300 & 1,430 & 1,540 \\
\hline $\mathrm{Bi}$ & $<5.9$ & $<5.5$ & 8.29 \\
\hline $\mathrm{Ca}$ & 24.9 & 24.9 & 43.5 \\
\hline $\mathrm{Cl}$ & 438 & 438 & 286 \\
\hline $\mathrm{CO}_{3}$ & 4,530 & 4,210 & 791 \\
\hline $\mathrm{Cr}$ & 110 & 190 & 272 \\
\hline $\mathrm{F}$ & $<161$ & $<25.7$ & 36.9 \\
\hline $\mathrm{Fe}$ & 1,030 & 61.6 & 19.3 \\
\hline $\mathrm{Hg}$ & NR & $\mathrm{NR}$ & 0.0559 \\
\hline $\mathrm{K}$ & 142 & 142 & 82.8 \\
\hline $\mathrm{Mn}$ & 19.8 & 19.8 & 6.42 \\
\hline $\mathrm{Na}$ & 17,600 & 21,300 & 10,800 \\
\hline $\mathrm{Ni}$ & 7.62 & 7.62 & 12.2 \\
\hline $\mathrm{NO}_{2}$ & 2,570 & 4,490 & 3,810 \\
\hline $\mathrm{NO}_{3}$ & 25,700 & 25,500 & 10,000 \\
\hline $\mathrm{Pb}$ & $<12$ & $<11$ & 6.39 \\
\hline $\mathrm{P}$ as $\mathrm{PO}_{4}$ & 641 & 562 & 260 \\
\hline $\mathrm{Si}$ & 14.0 & 14.0 & 70.3 \\
\hline $\mathrm{S}$ as $\mathrm{SO}_{4}$ & 1,360 & 1,350 & 728 \\
\hline $\mathrm{Sr}$ & $<0.5$ & $<0.5$ & 0 \\
\hline TOC & 770 & 770 & 361 \\
\hline U & $<32.5$ & $<32$ & 76.5 \\
\hline $\mathrm{Zr}$ & $<1.44$ & $<1.44$ & 0.695 \\
\hline
\end{tabular}


HNF-SD-WM-ER-689

Revision 0

Table D3-3. Tank 241-TX-101 Inventory Estimates for the SMMT2 Salt Cake Layer $($ Volume $=49.2 \mathrm{~kL}[13 \mathrm{kgal}])$. (2 Sheets)

\begin{tabular}{|c|c|c|c|}
\hline Analyte & $\begin{array}{c}\text { Inventory estimates } \\
\text { using T2SltCk } \\
\text { average } \\
\text { concentrations } \\
(\mathrm{kg})\end{array}$ & $\begin{array}{c}\text { Inventory estimates } \\
\text { using U tank farm } \\
\text { weighted mean } \\
\text { concentration } \\
(\mathrm{kg})\end{array}$ & $\begin{array}{c}\text { HDW-Based Inventory for } \\
\text { T2SltCk layer } \\
(\mathrm{kg})\end{array}$ \\
\hline Radionuclides $^{\mathrm{b}}$ (Ci) & \multicolumn{3}{|c|}{} \\
\hline${ }^{90} \mathrm{Sr}$ & $\mathrm{NR}$ & $\mathrm{NR}$ & 3,880 \\
\hline${ }^{137} \mathrm{Cs}$ & 33,600 & $\mathrm{NR}$ & 9,270 \\
\hline
\end{tabular}

HDW $=$ Hanford Defined Waste

$\mathrm{NR}=$ Not reported

SMM = Supernatant Mixing Model

a Agnew et al. (1997), SMM composite inventory estimate

${ }^{b}$ Radionuclides decayed to January 1, 1994.

\section{D3.4.2 Basis For Sludge Calculations Used In This Engineering Evaluation}

The R1 sludge concentrations used in this engineering assessment were developed with analytical data taken from TCRs for the following tanks: 241-S-101 (Kruger et al. 1996), 241-S-104 (DiCenso et al. 1994), and 241-S-107 (Simpson et al. 1996). Segment data for particular waste types were selected based on Agnew et al.'s (1997) predicted sludge location. The average concentrations from each tank and the segments used in the calculation are shown in Table D3-4. The mean from each tank was averaged to obtain the projected concentration for each analyte for the R1 sludge.

The HDW model values for the tank 241-TX-101 sludge layer are also listed in Table D3-4 for comparison with the R1 sludge values. The sludge layer inventory estimates using the engineering assessment values for R1 sludge are listed in Table D3-5 and are compared with HDW model sludge layer values for tank 241-TX-101. 
HNF-SD-WM-ER-689

Revision 0

Table D3-4. R1 Sludge Concentration Estimate (Volume $=280 \mathrm{~kL}[74.0 \mathrm{kgal}])$.

(2 Sheets)

\begin{tabular}{|c|c|c|c|c|c|}
\hline Analyte & $\begin{array}{c}241-\mathrm{S}-101 \\
\text { segments } \\
7{\mathrm{U}-8 \mathrm{~L}^{\mathrm{a}}}^{(\mu \mathrm{g} / \mathrm{g})}\end{array}$ & $\begin{array}{c}241-\mathrm{S}-104 \\
\text { total sludge } \\
\text { concentration } \\
(\mu \mathrm{g} / \mathrm{g})\end{array}$ & $\begin{array}{c}241-\mathrm{S}-107 \\
\text { segments } \\
7 \mathrm{U}-8 \mathrm{~L}^{\mathrm{c}} \\
(\mu \mathrm{g} / \mathrm{g})\end{array}$ & $\begin{array}{c}\text { Average } \\
\text { concentration } \\
(\mu \mathrm{g} / \mathrm{g})\end{array}$ & $\begin{array}{c}\text { HDW model } \\
\text { sludge } \\
\text { values for } \\
\text { R1 sludge } \\
(\mu \mathrm{g} / \mathrm{g})\end{array}$ \\
\hline $\mathrm{Al}$ & 127,000 & 117,000 & 56,400 & 100,000 & 107,000 \\
\hline $\mathrm{Bi}$ & $<38.8$ & $<45.7$ & $\mathrm{NR}$ & $<42.2$ & 0 \\
\hline $\mathrm{Ca}$ & 322 & 247 & 234 & 268 & 5,020 \\
\hline $\mathrm{Cl}$ & 2,050 & 3,200 & 1,860 & 2,370 & 1,040 \\
\hline $\mathrm{Cr}$ & 2,230 & 2,350 & 1,180 & 1,920 & 1,830 \\
\hline $\mathrm{F}$ & $<65.7$ & 145 & 150 & $<120$ & 0 \\
\hline $\mathrm{Fe}$ & 1,960 & 1,720 & 1,160 & 1,613 & 32,200 \\
\hline $\mathrm{K}$ & 539 & 300 & 457 & 432 & 250 \\
\hline $\mathrm{Mn}$ & 2,750 & 1,150 & 83 & 1,330 & 0 \\
\hline $\mathrm{Na}$ & 112,000 & 121,000 & 60,400 & 97,800 & 106,000 \\
\hline $\mathrm{Ni}$ & 90.7 & 56 & 206 & 118 & 1,690 \\
\hline $\mathrm{NO}_{2}$ & 31,100 & 25,900 & 34,300 & 30,433 & 38,200 \\
\hline $\mathrm{NO}_{3}$ & 119,000 & 191,000 & 57,600 & 122,500 & 187,000 \\
\hline $\mathrm{Pb}$ & 37 & 29.6 & 33 & 33.2 & 0 \\
\hline $\mathrm{PO}_{4}$ & 1,360 & $<2,190$ & 1,630 & $<1,730$ & 0 \\
\hline $\mathrm{Si}$ & 1,360 & 1,330 & 1,060 & 1,250 & 129 \\
\hline $\mathrm{SO}_{4}$ & 897 & 2,270 & 1,300 & 1,489 & 569 \\
\hline $\mathrm{Sr}$ & 456 & 424 & 378 & 420 & 0 \\
\hline $\mathrm{TOC}$ & $\mathrm{NR}$ & 1,730 & $\mathrm{NR}$ & 1,730 & 0 \\
\hline $\mathrm{U}$ & 7,684 & 6,690 & 8,685 & 7,690 & 207 \\
\hline $\mathrm{Zr}$ & 36 & 33.6 & 131 & 66.9 & 0 \\
\hline $\mathrm{density}$ & 1.77 & 1.64 & 1.90 & 1.77 & 1.75 \\
$(\mathrm{~g} / \mathrm{mL})$ & & & & & \\
\hline & & & & & 0 \\
\hline
\end{tabular}


HNF-SD-WM-ER-689

Revision 0

Table D3-4. R1 Sludge Concentration Estimate (Volume $=280 \mathrm{~kL}[74.0 \mathrm{kgal}]$ ).

(2 Sheets)

\begin{tabular}{|c|c|c|c|c|c|}
\hline Analyte & $\begin{array}{c}241-\mathrm{S}-101 \\
\text { segments } \\
7 \mathrm{U}-8 \mathrm{~L}^{\mathrm{a}} \\
(\mu \mathrm{g} / \mathrm{g})\end{array}$ & $\begin{array}{c}\text { 241-S-104 } \\
\text { total sludge } \\
\text { concentration } \\
(\mu \mathrm{g} / \mathrm{g})\end{array}$ & $\begin{array}{c}241-\mathrm{S}-107 \\
\text { segments } \\
7 \mathrm{U}-8 \mathrm{~L}^{\mathrm{c}} \\
(\mu \mathrm{g} / \mathrm{g})\end{array}$ & $\begin{array}{c}\text { Average } \\
\text { concentration } \\
(\mu \mathrm{g} / \mathrm{g})\end{array}$ & \begin{tabular}{c}
$\begin{array}{c}\text { HDW model } \\
\text { sludge } \\
\text { values for } \\
\text { R1 sludge } \\
(\mu \mathrm{g} / \mathrm{g})\end{array}$ \\
\hline \multicolumn{5}{|l|}{ Radionuclides }
\end{tabular}
\end{tabular}

HDW $=$ Hanford Defined Waste

$\mathrm{NR}=$ Not reported

${ }^{a}$ Kruger (1996), analysis in 1995

${ }^{b}$ DiCenso et al. (1994), analysis in 1994

- Simpson (1996), analysis in 1995

d Average of tanks 241-S-101, 241-S-104, and 241-S-107 sludge concentrations

e Agnew et al. (1997)

${ }^{f}$ Radionuclides decayed to January 1, 1994.

Table D3-5. Tank 241-TX-101 Inventory Estimates for the R1 Sludge Layer (Volume = $280 \mathrm{~kL}[74.0 \mathrm{kgal}])$. (2 Sheets)

\begin{tabular}{|c|c|c|}
\hline Analyte & $\begin{array}{c}\text { Inventory estimates using } \\
\text { R1 sludge }(\mathrm{kg})\end{array}$ & $\begin{array}{c}\text { HDW model values for sludge } \\
\text { layer }(\mathrm{kg})\end{array}$ \\
\hline $\mathrm{Al}$ & 49,900 & 51,100 \\
\hline $\mathrm{Bi}$ & $<21.0$ & 0 \\
\hline $\mathrm{Ca}$ & 134 & 2,440 \\
\hline $\mathrm{Cl}$ & 1,180 & 492 \\
\hline $\mathrm{CO}_{3}$ & $\mathrm{NR}$ & 4,900 \\
\hline $\mathrm{Cr}$ & 957 & 854 \\
\hline $\mathrm{F}$ & 59.8 & 0 \\
\hline $\mathrm{Fe}$ & 804 & 15,400 \\
\hline $\mathrm{Hg}$ & 0 & 0 \\
\hline $\mathrm{K}$ & 215 & 117 \\
\hline $\mathrm{Mn}$ & 663 & 0 \\
\hline $\mathrm{Na}$ & 48,800 & 51,000 \\
\hline $\mathrm{Ni}$ & 58.8 & 811 \\
\hline & & \\
\hline
\end{tabular}


Table D3-5. Tank 241-TX-101 Inventory Estimates for the R1 Sludge Layer (Volume = $280 \mathrm{~kL}[74.0 \mathrm{kgal}])$. (2 Sheets)

\begin{tabular}{|c|c|c|}
\hline Analyte & $\begin{array}{c}\text { Inventory estimates using } \\
\mathrm{R} 1 \text { sludge }(\mathrm{kg})\end{array}$ & $\begin{array}{c}\text { HDW model values for sludge } \\
\text { layer }(\mathrm{kg})\end{array}$ \\
\hline $\mathrm{NO}_{2}$ & 15,200 & 17,800 \\
\hline $\mathrm{NO}_{3}$ & 61,100 & 87,200 \\
\hline $\mathrm{OH}$ & $\mathrm{NR}$ & 120,000 \\
\hline $\mathrm{Pb}$ & 16.6 & 0 \\
\hline $\mathrm{PO}_{4}$ & $<861$ & 432 \\
\hline $\mathrm{Si}$ & 623 & 60.5 \\
\hline $\mathrm{SO}_{4}$ & 743 & 365 \\
\hline $\mathrm{Sr}$ & 209 & 0 \\
\hline $\mathrm{TOC}$ & 862 & 0 \\
\hline $\mathrm{U}$ & 3,830 & 4,830 \\
\hline $\mathrm{Zr}$ & 33.3 & 0 \\
\hline \multicolumn{2}{|c|}{} \\
\hline $\mathrm{Radionuclides}(\mathrm{Ci})$ & 38,500 & 14,900 \\
\hline${ }^{137} \mathrm{Cs}$ & 143,000 & 246,000 \\
\hline${ }^{90} \mathrm{Sr}$ & &
\end{tabular}

HDW = Hanford Defined Waste

NR $=$ Not reported

$\mathrm{TLM}=$ Tank layer model

"Agnew, et al. (1997), TLM solids composite inventory estimate.

\section{D3.4.3 Tank 241-TX-101 Inventory Estimates}

The tank 241-TX-101 inventory estimates calculated from sludge layer estimates and the salt cake layer are shown in Table D3-6. This table also lists HDW model estimates for this tank for comparison. Very good agreement (i.e., within a factor of approximately 0.25 ) between the HDW model estimates and the results of this engineering assessment is noted for

- $\mathrm{Al}, \mathrm{Cr}, \mathrm{Na}$, and nitrite. Reasonable agreement between the two estimates (i.e., within a factor of approximately 2) is noted for $\mathrm{Cl}, \mathrm{K}$, phosphate, nitrate, sulfate, and $\mathrm{U}$. Poor agreement (i.e., greater than a factor of 10 ) between the two estimates is noted for $\mathrm{Bi}, \mathrm{Ca}$, $\mathrm{F}, \mathrm{Fe}, \mathrm{Ni}, \mathrm{Mn}$, nonradioactive $\mathrm{Sr}$ and ${ }^{90} \mathrm{Sr}$.

Since neither of the data sets being compared contain any tank-specific analytical data, it difficult to favor one value over the other. However, some general trends that have been noted with other tanks may provide some insight. For example, the HDW model assumes high concentrations of iron for tank 241-TX-101 with 50 percent coming from corrosion of stainless steel equipment. Nickel and chromium are also expected from the corrosion of 
HNF-SD-WM-ER-689

Revision 0

stainless steel. However, the analytical data assessed in developing the R1 Sludge composition did not exhibit a correlation between $\mathrm{Fe}$ and $\mathrm{Ni}$.

The high concentrations of manganese found in the R1 Sludge is believed to have come the use of permanganate in some of the REDOX flowsheets. However, Agnew et al. (1997) fail to include manganese in the model. Thus, the manganese values are much higher in the engineering assessment than in the HDW model.

Until analytical results are available from samples taken from 241-TX-101, resolution of differences between the estimates is not possible.

Table D3-6. Tank 241-TX-101 Inventory Estimates (Volume $=329 \mathrm{~kL}$ [87 kgal]). (2 Sheets)

\begin{tabular}{|c|c|c|c|c|}
\hline Analyte & $\begin{array}{c}\text { Inventory } \\
\text { estimates for } \\
\text { R1 sludge layer } \\
(\mathrm{kg})\end{array}$ & $\begin{array}{l}\text { Inventory } \\
\text { estimates for } \\
\text { T2SItCk } \\
\text { layer }(\mathrm{kg})\end{array}$ & $\begin{array}{l}\text { Engineering } \\
\text { assessment-based } \\
\text { tank inventory } \\
\text { estimates }^{\mathrm{a}} \\
(\mathrm{kg})\end{array}$ & $\begin{array}{l}\text { HDW model tank } \\
\text { inventory } \\
\text { estimates }^{\mathrm{b}} \\
\quad(\mathrm{kg})\end{array}$ \\
\hline $\mathrm{Al}$ & 49,900 & 2,300 & 52,200 & 52,600 \\
\hline $\mathrm{Bi}$ & $<21.0$ & $<5.9$ & $<27$ & 8.29 \\
\hline $\mathrm{Ca}$ & 134 & 24.9 & 159 & 2,480 \\
\hline $\mathrm{Cl}$ & 1,180 & 438 & 1,620 & 778 \\
\hline $\mathrm{CO}_{3}$ & NR & 4,530 & 4,530 & 5,690 \\
\hline $\mathrm{Cr}$ & 957 & 110 & 1,070 & 1,130 \\
\hline F & 59.8 & $<161$ & $<221$ & 36.9 \\
\hline $\mathrm{Fe}$ & 804 & 61.6 & 866 & 15,400 \\
\hline $\mathrm{K}$ & 215 & 142 & 357 & 200 \\
\hline $\mathrm{Mn}$ & 663 & 19.8 & 683 & 6.42 \\
\hline $\mathrm{Na}$ & 48,800 & 17,600 & 66,400 & 61,800 \\
\hline $\mathrm{Ni}$ & 58.8 & 7.62 & 67 & 823 \\
\hline $\mathrm{NO}_{2}$ & 15,200 & 2,570 & 17,800 & 21,600 \\
\hline $\mathrm{NO}_{3}$ & 61,100 & 25,700 & 86,800 & 97,300 \\
\hline $\mathrm{Pb}$ & 16.6 & $<12$ & $<29$ & 6.39 \\
\hline $\mathrm{PO}_{4}$ & $<861$ & 641 & $<1,500$ & 691 \\
\hline $\mathrm{Si}$ & 623 & 14.0 & 637 & 131 \\
\hline $\mathrm{SO}_{4}$ & 743 & 1,360 & 2,100 & 1,090 \\
\hline $\mathrm{Sr}$ & 209 & $<0.5$ & 210 & 0 \\
\hline
\end{tabular}


HNF-SD-WM-ER-689

Revision 0

Table D3-6. Tank 241-TX-101 Inventory Estimates (Volume $=329 \mathrm{~kL}[87 \mathrm{kgal}]$ ).

(2 Sheets)

\begin{tabular}{|c|c|c|c|c|}
\hline Analyte & $\begin{array}{c}\text { Inventory } \\
\text { estimates for } \\
\text { R1 sludge layer } \\
(\mathrm{kg})\end{array}$ & $\begin{array}{c}\text { Inventory } \\
\text { estimates for } \\
\text { T2SltCk } \\
\text { layer }(\mathrm{kg})\end{array}$ & $\begin{array}{c}\text { Engineering } \\
\text { assessment-based } \\
\text { tank inventory } \\
\text { estimates }^{\mathrm{a}} \\
(\mathrm{kg})\end{array}$ & $\begin{array}{c}\text { HDW model tank } \\
\text { inventory } \\
\text { estimates } \\
(\mathrm{kg})\end{array}$ \\
\hline TOC & 862 & 770 & 1,630 & 361 \\
\hline $\mathrm{U}$ & 3,830 & $<32.5$ & $<3,860$ & 4,910 \\
\hline $\mathrm{Zr}$ & 33.3 & $<1.44$ & $<34.7$ & 0.695 \\
\hline Radionuclides $(\mathrm{Ci})$ & \multicolumn{5}{|l}{} \\
\hline${ }^{\mathrm{9}} \mathrm{Sr}$ & 93,700 & $\mathrm{NR}$ & 93,700 & 250,000 \\
\hline${ }^{137} \mathrm{Cs}$ & 72,300 & 33,600 & 106,000 & 24,100 \\
\hline
\end{tabular}

HDW $=$ Hanford Defined Waste

$\mathrm{NR}=$ Not reported

${ }^{2}$ Engineering assessment inventory estimates are the sum of $R 1$ sludge and $T 2$ salt cake estimates

${ }^{\mathrm{b}}$ Agnew et al. (1997). 
HNF-SD-WM-ER-689

Revision 0

\section{D4.0 DEFINE THE BEST-BASIS AND ESTABLISH COMPONENT INVENTORIES}

Information about chemical, radiological, and/or physical properties is used to perform safety analyses, engineering evaluations. and risk assessment associated with waste management activities, as well as regulatory issues. These activities include overseeing tank farm operations and identifying, monitoring, and resolving safety issues associated with these operations and with the tank wastes. Disposal activities involve designing equipment, processing and facilities for retrieving wastes and processing them into a form that is suitable for long-term storage.

Chemical and radiological inventory information are generally derived using three approaches: (1) component inventories are estimated using results of sample analyses, (2) component inventories are estimated using the HDW Model based on process knowledge and historical information, or (3) a tank-specific process estimate is made based on process flowsheets, reactor fuel data, essential material usage, and other operating data. Not surprisingly, the information derived from these different approaches is often inconsistent.

An evaluation of available chemical information for tank 241-TX-101 was performed, including the following:

- An inventory estimate generated by the HDW model (Agnew et al. 1997)

- Evaluation of SMMT2 data from two U Farm tanks (241-U-102 [Hu et al. 1997] and 241-U-105 [Brown and Franklin 1996]) and older characterization data from 241-TX-116.

- Evaluation of R1 Sludge from TCRs from tanks 241-S-101 (Kruger et al. 1996), 241-S-104 (DiCenso et al. 1994), and 241-S-107 (Simpson et al. 1996).

Based on this engineering assessment, an engineering assessment-based inventory was developed for tank 241-TX-101 (for which sample information was not available). When available, the engineering assessment-based inventory was chosen as the best-basis inventory for the following reasons:

- No analytical data is available for tank 241-TX-101.

- No independent data are available to predict SMMT2 salt cake from process flowsheets or historical records.

For those analytes where no values could be calculated from the engineering assessment-based inventory the HDW model values were used. Best-basis tank inventory values are derived for 46 key radionuclides (as defined in Section 3.1 of Kupfer et al. 1997), all decayed to a common report date of January 1,1994. Often, waste sample analyses have only reported ${ }^{90} \mathrm{Sr},{ }^{137} \mathrm{Cs}$, ${ }^{239 / 240} \mathrm{Pu}$, and total uranium or total beta and total alpha, while other 
key radionuclides such as ${ }^{60} \mathrm{Co},{ }^{99} \mathrm{Tc},{ }^{129} \mathrm{I},{ }^{154} \mathrm{Eu},{ }^{155} \mathrm{Eu}$, and ${ }^{241} \mathrm{Am}$, etc., have been infrequently reported. For this reason it has been necessary to derive most of the 46 key radionuclides by computer models. These models estimate radionuclide activity in batches of reactor fuel, account for the split of radionuclides to various separations plant waste streams, and track their movement with tank waste transactions. (These computer models are described in Kupfer et al. 1997, Section 6.1 and in Watrous and Wootan 1997.) Model generated values for radionuclides in any of 177 tanks are reported in the HDW Rev. 4 model results (Agnew et al. 1997). The best-basis value for any one analyte may be either a model result or a sample or engineering assessment-based result if available. (No attempt has been made to ratio or normalize model results for all 46 radionuclides when values for measured radionuclides disagree with the model.) For a discussion of typical error between model derived values and sample derived values, see Kupfer et al. 1997, Section 6.1.10.

Best-basis tables for chemicals and only four radionuclides $\left({ }^{90} \mathrm{Sr},{ }^{137} \mathrm{Cs}, \mathrm{Pu}\right.$, and $\left.\mathrm{U}\right)$ were being generated in 1996, using values derived from an earlier version (Rev. 3) of the HDW model. When values for all 46 radionuclides became available in Rev. 4 of the HDW model, they were merged with draft best-basis chemical inventory documents. Defined scope of work in FY 1997 did not permit Rev. 3 chemical values to be updated to Rev. 4 chemical values.

Once the best-basis inventories were determined, the hydroxide inventory was calculated by performing a charge balance with the valences of other analytes. In some cases, this approach requires that other analyte (e.g., sodium or nitrate) inventories be adjusted to achieve the charge balance. During such adjustments, the number of significant figures is not increased. This charge balance approach is consistent with that used by Agnew et al. (1997).

Since no post-1989 analytical data were available from this tank or any other tank with similar wastes within the TX Tank Farm, the reliability of these estimates (in either this engineering assessment or the HDW model inventory estimates) are suspect. Substantial uncertainty exists with regard to these estimates.

The best-basis values are listed in Tables D4-1 and D4-2. The inventory values reported in Tables D4-1 and D4-2 are subject to change. Refer to the Tank Characterization Database (TCD) for the most current inventory values. 
HNF-SD-WM-ER-689

Revision 0

Table D4-1. Best-Basis Inventory Estimates for Nonradioactive Components in

Tank 241-TX-101 (Effective May 31, 1997).

\begin{tabular}{|c|c|c|c|}
\hline Analyte & $\begin{array}{c}\text { Total } \\
\text { inventory } \\
(\mathrm{kg})\end{array}$ & $\begin{array}{c}\text { Basis } \\
(\mathrm{S}, \mathrm{M}, \text { or } \mathrm{E})^{1}\end{array}$ & Comment \\
\hline $\mathrm{Al}$ & 52,200 & $\mathrm{E}$ & . \\
\hline $\mathrm{Bi}$ & 8.29 & $\mathrm{M}$ & \\
\hline $\mathrm{Ca}$ & 159 & $\mathrm{E}$ & \\
\hline $\mathrm{Cl}$ & 1,620 & $\mathrm{E}$ & \\
\hline TIC as $\mathrm{CO}_{3}$ & 4,530 & $\mathrm{E}$ & \\
\hline $\mathrm{Cr}$ & 1,070 & $\mathrm{E}$ & \\
\hline $\mathrm{F}$ & $<221$ & $\mathrm{E}$ & \\
\hline $\mathrm{Fe}$ & 866 & $E$ & U Farm estimate used for $\mathrm{Fe}$ \\
\hline $\mathrm{Hg}$ & 0.0559 & $\mathrm{M}$ & \\
\hline $\mathbf{K}$ & 357 & $\mathrm{E}$ & \\
\hline $\mathrm{La}$ & 0.127 & $\mathrm{M}$ & \\
\hline $\mathrm{Mn}$ & 683 & $\mathrm{E}$ & \\
\hline $\mathrm{Na}$ & 66,400 & $\mathrm{E}$ & \\
\hline $\mathrm{Ni}$ & 67 & $\mathrm{E}$ & \\
\hline $\mathrm{NO}_{2}$ & 17,800 & $\mathrm{E}$ & \\
\hline $\mathrm{NO}_{3}$ & 86,800 & $E$ & \\
\hline $\mathrm{OH}_{\text {TOTAI }}$ & 116,000 & $\mathrm{C}$ & \\
\hline $\mathrm{Pb}$ & $<29$ & $\mathrm{E}$ & \\
\hline $\mathrm{PO}_{4}$ & $<1,500$ & $\mathrm{E}$ & \\
\hline $\mathrm{Si}$ & 637 & $\mathrm{E}$ & \\
\hline $\mathrm{SO}_{4}$ & 2,100 & $\mathrm{E}$ & \\
\hline $\mathrm{Sr}$ & 210 & $E$ & \\
\hline TOC & 1,630 & $E$ & \\
\hline $\mathrm{U}_{\text {TOTAL }}$ & $<3,860$ & $\mathrm{E}$ & \\
\hline $\mathrm{Zr}$ & 0.695 & $\mathrm{M}$ & \\
\hline
\end{tabular}

$\mathrm{CO}_{3}, \mathrm{NO}_{2}, \mathrm{NO}_{3}, \mathrm{PO}_{4}, \mathrm{SO}_{4}$, and $\mathrm{SiO}_{3}$. 


\section{HNF-SD-WM-ER-689}

Revision 0

Table D4-2. Best-Basis Inventory Estimates for Radioactive Components in Tank 241-TX-101 Decayed to January 1, 1994 (Effective May 31, 1997). (2 Sheets)

\begin{tabular}{|c|c|c|l|}
\hline Analyte & $\begin{array}{c}\text { Total } \\
\text { inventory } \\
(\mathrm{Ci})\end{array}$ & $\begin{array}{c}\text { Basis } \\
(\mathrm{S}, \mathrm{M}, \text { or } \mathrm{E})\end{array}$ & \\
\hline${ }^{3} \mathrm{H}$ & 16.1 & $\mathrm{M}$ & \\
\hline${ }^{14} \mathrm{C}$ & 1.8 & $\mathrm{M}$ & \\
\hline${ }^{59} \mathrm{Ni}$ & 4.01 & $\mathrm{M}$ & \\
\hline${ }^{60} \mathrm{Co}$ & 1.51 & $\mathrm{M}$ & \\
\hline${ }^{63} \mathrm{Ni}$ & 375 & $\mathrm{M}$ & \\
\hline${ }^{79} \mathrm{Se}$ & 0.245 & $\mathrm{M}$ & \\
\hline${ }^{90} \mathrm{Sr}$ & 143,000 & $\mathrm{M}$ & \\
\hline${ }^{90} \mathrm{Y}$ & 143,000 & $\mathrm{M}$ & \\
\hline${ }^{93} \mathrm{Zr}$ & 1.18 & $\mathrm{M}$ & \\
\hline${ }^{93 \mathrm{~m}} \mathrm{Nb}$ & 0.914 & $\mathrm{M}$ & \\
\hline${ }^{99} \mathrm{Tc}$ & 12.5 & $\mathrm{M}$ & \\
\hline${ }^{106} \mathrm{Ru}$ & $2.24 \mathrm{E}-04$ & $\mathrm{M}$ & \\
\hline${ }^{113 \mathrm{~m}} \mathrm{Cd}$ & 4.86 & $\mathrm{M}$ & \\
\hline${ }^{125} \mathrm{Sb}$ & 5.78 & $\mathrm{M}$ & \\
\hline${ }^{126} \mathrm{Sn}$ & 0.374 & $\mathrm{M}$ & \\
\hline${ }^{129} \mathrm{~T}$ & 0.0241 & $\mathrm{M}$ & \\
\hline${ }^{134} \mathrm{Cs}$ & 0.0916 & $\mathrm{M}$ & \\
\hline${ }^{137} \mathrm{Cs}$ & 72,100 & $\mathrm{E}$ & \\
\hline${ }^{137 \mathrm{~m}} \mathrm{Ba}$ & 68,100 & $\mathrm{E}$ & Referenced to ${ }^{137} \mathrm{Cs}$ \\
\hline${ }^{151} \mathrm{Sm}$ & 871 & $\mathrm{M}$ & \\
\hline${ }^{152} \mathrm{Eu}$ & 1.98 & $\mathrm{M}$ & \\
\hline${ }^{154} \mathrm{Eu}$ & 26.5 & $\mathrm{M}$ & \\
\hline${ }^{155} \mathrm{Eu}$ & 95.3 & $\mathrm{M}$ & \\
\hline${ }^{226} \mathrm{Ra}$ & $2.93 \mathrm{E}-04$ & $\mathrm{M}$ & \\
\hline${ }^{227} \mathrm{Ac}$ & 0.00130 & $\mathrm{M}$ & \\
\hline${ }^{228} \mathrm{Ra}$ & 0.00420 & $\mathrm{M}$ & \\
\hline${ }^{229} \mathrm{Th}$ & $9.90 \mathrm{E}-05$ & $\mathrm{M}$ & \\
\hline${ }^{231} \mathrm{~Pa}$ & $3.39 \mathrm{E}-04$ & $\mathrm{M}$ & \\
\hline${ }^{232} \mathrm{Th}$ & $2.78 \mathrm{E}-04$ & $\mathrm{M}$ & \\
\hline${ }^{232} \mathrm{U}$ & 0.0221 & $\mathrm{M}$ & \\
\hline
\end{tabular}


HNF-SD-WM-ER-689

Revision 0

Table D4-2: Best-Basis Inventory Estimates for Radioactive Components in Tank 241-TX-101 Decayed to January 1, 1994 (Effective May 31, 1997). (2 Sheets)

\begin{tabular}{|c|c|c|l|}
\hline Analyte & $\begin{array}{c}\text { Total } \\
\text { inventory } \\
(\mathrm{Ci})\end{array}$ & $\begin{array}{c}\text { Basis } \\
(\mathrm{S}, \mathrm{M}, \text { or } \mathrm{E})^{1}\end{array}$ & Comment \\
\hline${ }^{233} \mathrm{U}$ & 0.0847 & $\mathrm{M}$ & \\
\hline${ }^{234} \mathrm{U}$ & 1.62 & $\mathrm{M}$ & \\
\hline${ }^{235} \mathrm{U}$ & 0.0727 & $\mathrm{M}$ & \\
\hline${ }^{236} \mathrm{U}$ & 0.0113 & $\mathrm{M}$ & \\
\hline${ }^{237} \mathrm{~Np}$ & 0.0582 & $\mathrm{M}$ & \\
\hline${ }^{238} \mathrm{Pu}$ & 1.80 & $\mathrm{M}$ & \\
\hline${ }^{238} \mathrm{U}$ & 1.64 & $\mathrm{M}$ & \\
\hline${ }^{239} \mathrm{Pu}$ & 232 & $\mathrm{M}$ & \\
\hline${ }^{240} \mathrm{Pu}$ & 44.5 & $\mathrm{M}$ & \\
\hline${ }^{241} \mathrm{Am}$ & 115 & $\mathrm{M}$ & \\
\hline${ }^{241} \mathrm{Pu}$ & 108 & $\mathrm{M}$ & \\
\hline${ }^{242} \mathrm{Cm}$ & 0.0475 & $\mathrm{M}$ & \\
\hline${ }^{242} \mathrm{Pu}$ & $5.00 \mathrm{E}-04$ & $\mathrm{M}$ & \\
\hline${ }^{243} \mathrm{Am}$ & $8.68 \mathrm{E}-05$ & $\mathrm{M}$ & \\
\hline${ }^{243} \mathrm{Cm}$ & 0.00143 & $\mathrm{M}$ & \\
\hline${ }^{244} \mathrm{Cm}$ & 0.00520 & $\mathrm{M}$ & \\
\hline
\end{tabular}

${ }^{1} \mathrm{~S}=$ Sample-based

$M=$ Hanford Defined Waste model-based, Agnew et al. (1997)

$\mathrm{E}=$ Engineering assessment-based. 
HNF-SD-WM-ER-689

Revision 0

This page intentionally left blank.

D-24 
HNF-SD-WM-ER-689

Revision 0

\section{D5.0 APPENDIX D REFERENCES}

Agnew, S. F., R. A. Corbin, T. B. Duran, and K. A. Jurgensen, T.P. Ortiz, and

B. L. Young, 1995, Waste Status and Transaction Record Summary (WSTRS, Rev. 2), WHC-SD-WM-TI-615,-614,-669,-689, Rev. 2, Los Alamos National Laboratory, Los Alamos, New Mexico.

Agnew, S. F., J. Boyer, R. A. Corbin, T. B. Duran, J. R. FitzPatrick, K. A. Jurgensen, T. P. Ortiz, and B. L. Young, 1997, Hanford Tank Chemical and Radionuclide. Inventories: HDW Model Rev. 4, LA-UR-96-3860, Los Alamos National Laboratory, Los Alamos, New Mexico.

Brevick, C. H., 1995, Supporting Document for the Historical Tank Content Estimate for TX Tank Farm, WHC-SD-WM-ER-321, Westinghouse Hanford Company, Richland, Washington.

Brown, T. D. and J. D. Franklin, 1996, Tank Characterization Report for Single-Shell Tank 24I-U-105, WHC-SD-WM-ER-617, Rev. 0, Westinghouse Hanford Company, Richland, Washington.

DiCenso, A. T., L. C. Amato, J. D. Franklin, G. L. Nuttall, K. W. Johnson, P. Sathyanarayana, and B. C. Simpson, 1994, Tank Characterization Report for Single-Shell-Tank 241-S-104, WHC-SD-WM-ER-370, Rev. 0, Westinghouse Hanford Company, Richland, Washington.

Hanlon, B. M., 1996, Waste Tank Summary Report for Month Ending June 30, 1996, WHC-EP-0182-99, Westinghouse Hanford Company, Richland, Washington.

Hill, J. G., G. S. Anderson, and B. C. Simpson, 1995, The Sort on Radioactive Waste Type Model: A Method to Sort Single-shell Tanks into Characteristic Groups, PNL-9814, Rev. 2, Pacific Northwest Laboratory, Richland, Washington.

Hodgson, K. M, and M. D. LeClair, 1996, Work Plan for Defining a Standard Inventory Estimate for Wastes Stored in Hanford Site Underground Tanks, WHC-SD-WM-WP-311, Rev. 1, Lockheed Martin Hanford Corporation, Richland, Washington.

Horton, J. E., 1977, Physical and Chemical Characterization of 116-TX, Letter Report, Atlantic Richfield Hanford Company, Richland, Washington.

Hu, T. A., L. C. Amato, R. T. Winward, and R. D. Cromar, 1997, Tank Characterization Report for Single-Shell Tank 241-U-102, HNF-SD-WM-ER-618, Rev. 0, Lockheed Martin Hanford Corporạtion, Richland, Washington. 
HNF-SD-WM-ER-689

Revision 0

Kruger, A. A., B. J. Morris, and L. J. Fergestrom, 1996, Tank Characterization Report for Single-Shell Tank 241-S-101, WHC-SD-WM-ER-613, Rev. 0, Westinghouse Hanford Company, Richland, Washington.

Kupfer, M. J., A. L. Boldt, B. A. Higley, K. M. Hodgson, L. W. Shelton, B. C. Simpson, and R. A. Watrous (LMHC), S. L. Lambert, and D. E. Place (SESC), R. M. Orme (NHC), G. L. Borsheim (Borsheim Associates), N. G. Colton (PNNL), M. D. LeClair (SAIC), R. T. Winward (Meier Associates), and W. W. Schulz (W²S Corporation), 1997, Standard Inventories of Chemicals and Radionuclides in Hanford Site Tank Wastes, HNF-SD-WM-TI-740, Rev. 0, Lockheed Martin Hanford Corporation, Richland, Washington.

Rodenhizer, D. G., 1987, Hanford Waste Tank Sluicing History, WHC-SD-WM-TI-302, Westinghouse Hanford Company, Richland, Washington.

Simpson, B. C., J. G. Field, D. W. Engel, and D. S. Daly, 1996, Tank Characterization Report for Single-Shell Tank 241-S-107, WHC-SD-WM-ER-589, Rev. 0, Westinghouse Hanford Company, Richland, Washington.

Watrous, R. A., and D. W. Wootan, 1997, Activity of Fuel Batches Processed Through Hanford Separations Plants, 1944 Through 1989, HNF-SD-WM-TI-794, Rev. 0, Lockheed Martin Hanford Corporation, Richland, Washington. 